November 2021

\title{
Collaborative Learning of International Undergraduate English Language Learners in Small-group Writing Communities
}

Yiting Chu

University of Louisiana at Monroe, chu@ulm.edu

Follow this and additional works at: https://digitalcommons.georgiasouthern.edu/ij-sotl

\section{Recommended Citation}

Chu, Yiting (2021) "Collaborative Learning of International Undergraduate English Language Learners in Small-group Writing Communities," International Journal for the Scholarship of Teaching and Learning: Vol. 15: No. 2, Article 16.

Available at: https://doi.org/10.20429/ijsotl.2021.150216 


\title{
Collaborative Learning of International Undergraduate English Language Learners in Small-group Writing Communities
}

\begin{abstract}
This article reports a study on how international English language learner (ELL) students participated in a collaborative learning community comprised of peers and peer tutors in a writing center in a U.S. university. Drawing on the theory of community of practice (CoP), qualitative data were collected from weekly observations of three groups and in-depth interviews with four ELL students and six tutors. Findings suggested that these three groups functioned differently as CoPs with varied levels of participation and social interaction among the students and between students and tutors. A mismatch between the goals and roles of the students and those of the tutors, and group dynamics among students and between students and tutors were discussed. Implications for practices and research to better support international ELL students were discussed.
\end{abstract}

\section{Keywords}

collaborative learning, English language learners, higher education, peer writing tutoring, learning communities

\section{Creative Commons License}

(c) $($ ) $(\ominus$

This work is licensed under a Creative Commons Attribution-Noncommercial-No Derivative Works 4.0 License.

\section{Cover Page Footnote}

I thank Dr. Mike Knapp, Dr. Kara Jackson, and Dr. Heather Hebard for their expertise and comments on earlier drafts of this article. I am also grateful for the constructive feedback and helpful suggestions provided by the reviewers and journal editors. Finally, I thank Jenny Halpin and all my participants, without whom this study would not have been possible. 
IJ-SoTL, Vol. 15 [2021], No. 2, Art. 16

\title{
Collaborative Learning of International Undergraduate ELL Students in Small-group Writing Communities
}

\author{
Yiting Chu \\ University of Louisiana Monroe \\ Received: 4 May 2021;Accepted: 7 July 2021
}

\begin{abstract}
This article reports a study on how international English language learner (ELL) students participated in a collaborative learning community comprised of peers and peer tutors in a writing center in a U.S. university. Drawing on the theory of community of practice (CoP), qualitative data were collected from weekly observations of three groups and in-depth interviews with four ELL students and six tutors. Findings suggested that these three groups functioned differently as CoPs with varied levels of participation and social interaction among the students and between students and tutors. A mismatch between the goals and roles of the students and those of the tutors, and group dynamics among students and between students and tutors were discussed. Implications for practices and research to better support international ELL students were discussed.
\end{abstract}

A fast growth of international students is observed in institutions of higher education (IHEs) around the world. In the 2019-2020 academic year, I,075,496 international students were enrolled in the U.S. IHEs, which once again made United States the top host country of international students (Institute of International Education, 2020). Many of these international students in the United States are English language learners (ELLs). Perceived language (English) deficiency (Caplan \& Stevens, 20I7; Kim, 20I2; Lin, 20I5) and prior schooling and cultural experiences (Cox, 20I I; Nan, 20I2) often render these students in marginalized position in the English academic community and make them feel incompetent compared with domestic, native English-speaking counterparts (Cox \& Zawacki, 20I4; Fernsten, 2008). The writing center is one of the places international ELL students seek help on their writing projects and is an important informal teaching and learning space that supports their academic socialization.

The writing center has a long history in the IHEs in the U.S. where students can work and get help on their writing projects outside classroom (Munje et al., 20I8; Williams \& Takaku, 20I I) The most common practice adopted by many U.S. writing centers is a non-directive, interactive approach that engages writers in conversation and collaboration with peer tutors (Harris, 1995; Williams \& Severino, 2004). This practice is based on the writing center research since the 1980s that views writing tutoring as a collaborative learning process where writers interact and work with peer writing tutors with whom they share similar backgrounds, experiences, and status (Bruffee, 1984; Lunsford, 1991; Williams \& Severino, 2004).This approach, however, has been questioned when tutoring international, ELL writers, who often have different English writing experiences and expectations of the writing center (Blau et al., 200 I; Moussu \& David, 20 I5; Williams \& Severino, 2004). This is because, unlike their native English-speaking peers, international ELL students are not only using writing as a learning tool, i.e., writing to learn (Cox \& Zawacki, 20I4), but also in the process of learning to write English as a new language in an unfamiliar cultural and learning environment (Manchón, 20 I I).

This article aims to contribute to the scholarship of teaching and learning (SoTL) by exploring how a group of international undergraduate ELLs participated in a collaborative, writing tutoring program housed in a university writing center in the U.S.This program offers informal facilitated, peer tutoring to support inter- national ELL students' learning in writing intensive (WI) courses. Study findings provide insights into factors influencing international ELL writers' learning in this program and the ways in which continuous innovations can be developed towards improving the teaching and learning of the growing multilingual students in IHEs worldwide.

\section{PEER TUTORING AND INTERNATIONAL ELL STUDENTS IN WRITING CENTERS}

Peer tutoring is a type of collaborative learning that is based on the belief that learning is most likely to happen when peer learners collaborate with each other in social learning activities to construct knowledge and negotiate meanings (Bruffee, 1984, 1998; Lunsford, 1991). The peer tutoring model is widely adopted by writing centers across the U.S. and much research indicates that the collaborative, peer learning opportunities not only help improve students' writing abilities (Griswold, 2003; Williams \& Takaku, 20I I) but also provides a space outside the traditional classroom setting that prioritizes student agency and ownership of the writing process (Hathaway, 20I5; Munje et al., 2018).

A growing number of English writing scholars and practitioners has begun to challenge the established peer tutoring practices that grew out of the American academic writing culture in order to embrace the learning needs of culturally and linguistically diverse student writers (Blau et al., 2002; Cheatle, 2017; Cox \& Zawacki, 20 I4; Moussu \& David, 20I5;Thonus, 20I4). For example, researchers found that international ELL students often expect their tutors to "take on authoritative roles or at least to take on a variety of roles in response to learners' needs" (Williams \& Severino, 2004, p. 166). These students also view writing tutors as important sources to learn about the English language and local cultures and facilitate their transition to the academic English learning environment (Blau et al., 2002). These expectations are often at odds with the non-directive, process-oriented approach adopted by many writing tutors who are trained to work with native English writers, leading to many international ELL students' unsatisfied tutoring experiences when they feel that their tutors are not as helpful as they expected (Cheatle, 2017; Moussu \& David, 20I5).

Additional studies find that ELL writers often benefit more from working on writing projects in pairs or in small groups 
in formal classroom settings (Shehadeh, 2011;Wigglesworth \& Storch, 2012) and from collaborating with native English peer tutors in informal settings (Powers \& Nelson, 1995). For example, a series of studies conducted in Australia find that a writing group is an effective way to create a sustained space for writers, including international and ELL student writers, to work together on their writing projects (Aitchison, 2009; Aitchison \& Guerin, 2014). The benefits of collaborative, peer learning have also been identified in the broader SoTL (Tsang, 20I I). In addition, there seems to be no consensus about the impact of applying a non-directive approach-where the tutors engage student writers in explorative conversations instead of telling them what to do- when tutoring ELL writers (Gillespie \& Lerner, 2008; Thonus, 20I4).

To date, while the benefits of peer tutoring in writing have been documented, most existing studies are conducted in formal classrooms or one-to-one conferencing/ tutoring sessions and many of the assumptions and practices of writing tutoring are still primarily based on the experiences of tutoring native English-speaking students. Little is known about the experiences of ELL students in informal writing tutoring groups consisting of peers and peer tutors. This study extends this literature by examining the learning experiences of international ELL students in a small-group, peer tutoring program at a U.S. university. The research question that guided this inquiry was: How did undergraduate international ELL students participate and collaborate with peers and peer tutors in writing tutoring groups in a U.S. university?

\section{CONCEPTUAL FRAMEWORK}

The notion of community of practice (CoP) provides the conceptual tools for understanding how undergraduate international ELL students participate in the investigated program. Wenger et al. (2002) define CoPs as "groups of people who share a concern, set of problems, or a passion about a topic, and who deepen their knowledge and expertise in this area by interacting on an ongoing basis" (p. 4). Members of a CoP bound by shared values and concerns participate, interact, and help each other in a regular basis to generate new knowledge and improve practices that not only matter to themselves as individuals but also pertain to the community as a whole (Lave \&Wenger, 1991).

Lave and Wenger (199I) first develop this idea when they describe how learning takes place through the participation of and interaction between novices and experts in situated, social learning contexts. The newcomers of a CoP learn through "legitimate peripheral participation" (Lave \&Wenger, I 99।, p. 29), starting at the periphery of the community and moving towards full, competent membership as they participate jointly with more experienced members in communal practices and activities (Lave \& Wenger, 1991). In this way, learning can be understood as a process that newcomers of the CoP are socialized into the community cultures and norms and solidify their identity through co-negotiation of meaning.

Wenger and his colleagues later identify three dimensions of CoP: a domain of knowledge, a community, and a shared practice (Wenger et al., 2002). The domain consists of issues or problems that are of significance to the value and identity of the members; community is the sum of the social relationships and interactions among members that provide the space for negotiation of meaning; and a shared social practice developed and maintained by members helps bind the community together (Wenger, 1998;
Wenger et al., 2002). Participating in activities in CoPs is fundamental for the forming and sustaining of the community and for members of the community to learn (Wenger, 1998; Wenger et al., 2002). The domain of the community provides the goal of the participation while the community offers the chance for members to engage with one another in order to participate. This committed collaboration is an important aspect of the CoP theory because learners bond together in the community by the collaborative learning practice. In addition, Wenger et al. (2002) posit that the perceived values members gain from participating is critical to the maintaining of the CoPs, including both shortterm values that are conducive to members' experiences in the CoP and long-terms benefits that are valuable to CoP members' personal and professional development.

CoP is a helpful framework to examine experiences in this study: the writing tutoring program provides opportunities for international ELL students to form learning communities with peers and peer tutors that bear the potentials to creating CoPs. The small-group setting allows them to engage in collaborative learning, negotiate shared goals, and participate in community practices in collaboration with one another and with the tutors, who are the more experienced community members in writing knowledge and sometimes also in disciplinary knowledge. Therefore,

\section{METHODOLOGY}

A qualitative multiple case study was conducted to analyze in-depth international ELL students' learning in each group and to identify patterns across different groups (Merriam \& Tisdell, 2016). A multiple case study design was appropriate because each group constituted a bounded system as a unique case within the investigated program (Yin, 2017).A case study design also allowed for greater analytic attention to the contextual complexities within each group (Yin, 2017) and the interplay among students and between students and their tutors that influenced their learning experiences.

\section{Research Setting}

This study was situated in an interdisciplinary writing center located in a public university in the Northwestern United States. Writing tutors were graduate and undergraduate students from a variety of academic and linguistic backgrounds and were recruited through a competitive hiring process. The writing center adopted a non-directive, peer tutoring philosophy that expected tutors to engage student writers in reflective conservation about their writing projects during one-to-one tutoring sessions through rhetorical and open-ended questions in order for the writers to discover what they wanted to say instead of directly correcting or editing their essays. The program reported here was targeted specifically for undergraduate international ELL students enrolled in WI courses. The purpose of this program was to support the learning of these students in a collaborative learning community outside classroom. Tutors working for the program received a half-day training on group tutoring and cross-cultural communication, in addition to their regular annual training that focused on the non-directive peer tutoring procedures. Neither disciplinary knowledge nor specific linguistic background (e.g., native English-speaking status or knowledge of the first language of the students) was expected to tutor in this program. 
Information about this program was first shared via emails to course instructors and then, with instructor permission, by class visits presented by writing tutors. Students who were interested voluntarily signed up for the program and were grouped with two to four other students from the same class and two writing tutors. Students first met their group members at the program orientation where they also received information about the program purposes and expectations. The same groups of students and tutors met regularly-usually once a week for an hour-during the whole term and worked on course assignments and projects.

\section{Research Participants}

A total of 10 writers and six tutors in three groups participated in this study. Maximum variation principle (Merriam \& Tisdell, 2016) was used to select groups with participants from diverse demographic, linguistic, and academic backgrounds.All participants voluntarily gave their informed consent to participate. Table I summarizes the demographic information of the research participants. students who declined the invitation showed lower level of participation in their respective groups. All six tutors were invited and agreed to be interviewed. These semi-structured interviews lasted from 45 to 60 minutes. Students were asked about their roles in the group activities, collaboration with peers and peer tutors, and perceptions of their learning experiences in the program. Tutors were asked to share their perceptions of and reflections on the participation of the students and themselves in the groups. All interviews were audio recorded with participant permission.

The third thread of data was collected by reviewing documents related to the program and the tutoring sessions, including orientation materials (for writers), tutor training materials, and the reflective notes tutors recorded after each group meeting. The results presented in this article were primarily drawn from interviews and observations, with program documents and tutor notes being used for contextualization and triangulation purposes (Merriam \& Tisdell, 2016).

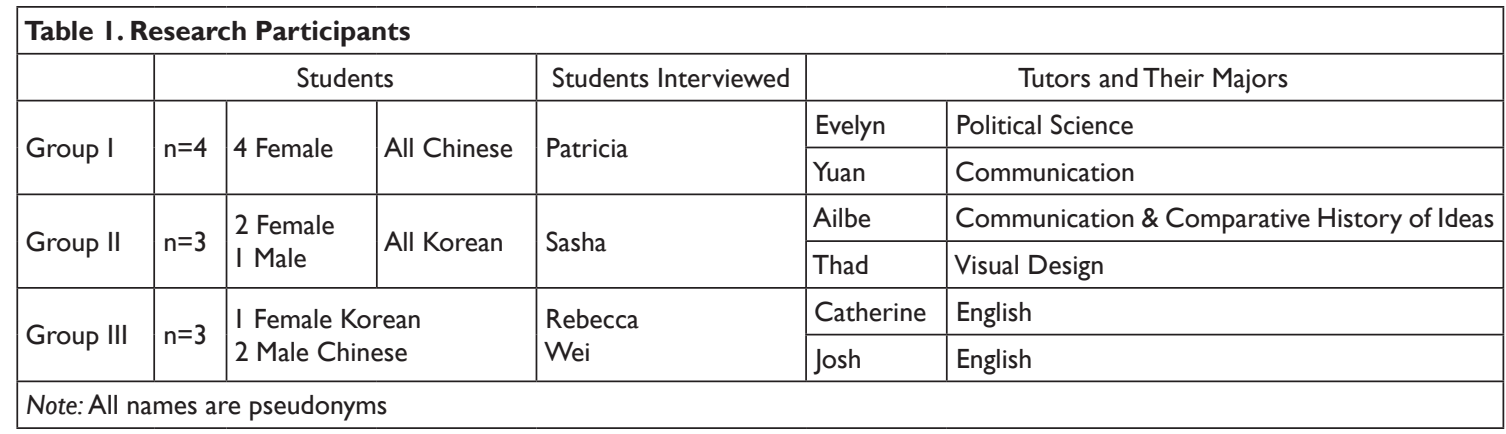

The two tutors in Group I were a Chinese male who was fluent in both Chinese and English and a Chinese American female who spoke only English. One of the tutors in Group II was a graduating senior, White English-speaking female and the other was a second-year Chinese Canadian student who was fluent in both English and Chinese. Group III had two White, monolingual English-speaking tutors who were English majors. Their tutoring experiences ranged from one to four years when this study was conducted.

\section{DATA COLLECTION}

Qualitative data were collected through non-participant observations, semi-structured interviews, and document analysis. The researcher attended all 24 weekly meetings of the three groups, eight for each, and took field notes. Attention was given to students' participation in the social learning tasks and their interaction and collaboration with one another and with the tutors, as well as the dynamics of the groups.

At the end of the term, two students from each group were invited to participate in an individual, semi-structured interview. Maximum variation sampling was used to select interview participants who represented the range of characteristics and patterns found within the sample (Merriam \& Tisdell, 20I6). Specifically, one student who had actively participated in group discussion and collaboration and one showed the least engagement from each group were invited with the intent to understand what might have contributed to their different participation patterns. However, only four of the six students agreed to be interviewed and both

\section{DATA ANALYSIS}

Following qualitative research conventions (Merriam \& Tisdell, 2016), data analysis began with the first observation and went through the entire data collection process. Observation notes were typed into narrative formats immediately after each observation, along with comments and notes on what to look for in subsequent observations and potential interview questions. Interview recordings were transcribed verbatim by the researcher. All observation notes, interview transcripts, and relevant documents were then imported into ATLAS. ti, a qualitative data analysis software, for analysis.

Data analysis started with inductive, open codes capturing participants' engagement and interaction in group activities. Free nodes were created and marked by key words and phrases for possible categories during this stage of coding. Initial codes were continuously revised and refined as more materials were collected and coded against existing data, using the constant comparative analysis strategy (Corbin \& Strauss, 20I5). For example, the "learning goals" code captured the variety of goals students and tutors wanted to achieve from participating in the program (e.g., improving English writing and getting help with course materials). Other examples included "shared practices" "perceived benefits" and "sense of community," which were directly linked to the CoP theory.

Axial coding was then used to compare codes across participants and establish themes (Corbin \& Strauss, 20I5). For example, the code "goal alignment" characterized how students' perceived alignment of goals influenced their participation and collaboration 
with peers and peer tutors in the groups. Interview transcripts, observation notes, and draft interpretation were shared with participants for member checking, whose feedback and insights were incorporated to ensure the accuracy and credibility of the results (Merriam \& Tisdell, 2016).

\section{FINDINGS}

Findings were presented around ELL student experiences in the three groups. Each of the three groups showed varied characteristics in relation to the three dimensions of CoP.

\section{Group I: Co-led Highly-active Community}

All four students in Group I were taking an introductory international studies course. While they had to prepare a portfolio as the final project, which consisted of two major papers and several short essays, they were equally concerned about understanding the content materials, which was both documented by observation of their group meetings and confirmed during interviews. Patricia, one of the students in Group I, explained in the interview that she was drawn to the program because she was afraid that she might not "understand some of the concepts or might not be able to finish the readings so [she] could check with the tutors."

One of the major activities this group did was to go over the lecture slides. This practice was first proposed by Patricia, who had a similar activity in the previous term for another course and found it very helpful.This suggestion was immediately accepted by other group members because they were also concerned about the subject content, which they needed to write about for their papers. This activity was conducted in a way of reviewing the class slides and notes together, during which the students often cross-checked each other's understandings of the materials by taking turns to answer questions like "What do you remember from this slide?" "What's that term?" or "What do these things mean?" Patricia also described the kind of collaboration in her group: "It's like if you don't understand something, like a concept, someone in the group might know the concept and could explain to you and when you know something you can also explain to others." Therefore, this practice was not only a way for them to accomplish the shared goals of the community but also to ensure accountability and collaboration within the group by setting the norm that everyone should contribute to the learning tasks.

When being asked about her roles in the group, Evelyn, one of the tutors, said that she originally wanted to be a facilitator who "ask[s] questions that gets like encourages them to think, then to make connections, and then to discuss, and then some sort of like can hold information together like help one another:' However, she admitted that she might end up being perceived by some students as a "resource person" or "insider" because of her knowledge in international studies and the fact that she had taken a similar class in the previous year. Occasionally, Evelyn led the review and explained the concepts to the group. The other tutor, Yuan, also called himself "facilitator" and described his role as guiding the group discussion. These perceptions were confirmed by Patricia, who described Evelyn as "professional and very supportive," by which she meant her disciplinary knowledge; and Yuan as competent in moving the conversation forward. As Patricia noted, because Yuan was not in a related major, he mostly contributed in maintaining the flow of the discussion and could "come up with suggestions very quickly when we did not know how to continue or had nothing to say, so we can make the tran- sition." Observations of the group meetings also confirmed that both tutors played scaffolding roles by encouraging the students to generate and elaborate on their ideas, summarizing what they said, and giving suggestions.

It was evident from the observations and interviews that ELL students and their tutors played active roles in this group in terms of creating and implementing group activities and contributing to achieving the shared goals and that both parties were appreciative of the participation of the other side. There was a high level of interaction and collaboration both between students and tutors and among students themselves, hence the classification of this group as a "co-led highly-active community."

\section{Group II: Student-led Active Community}

The three students in Group II were taking the same international studies class. Similar to Group I, the group meetings focused on disciplinary content; yet they did spend significant time on writing-related activities such as brainstorming essay ideas and peer reviewing. This choice was related to the students' understandings of writing and of the class, and their perceived goals of the program. Sasha, one of the students, explained her rational of signing up for this program:
Although this class is not an English class, you have to read a lot of books and since those books are not easy, I figured that l'd have a hard time understanding all the content by myself. Then I thought, being surrounded with people whose first language was not English would help me to, um... under- stand the materials better.

She later explained that she and the other two students all prioritized the challenging materials and were less worried about writing, which she deemed as grammar.

Students in this group took significantly more dominant roles compared with their counterparts in the other two groups. This was primarily due to the fact that neither of the two tutors had background knowledge of international studies. Sasha explained in the interview that they originally expected the tutors to help them with the materials and prepared to be "guided by the tutors." However, they had to modify their plans and came up with alternative practices after they realized the tutors' limited content knowledge. Sasha explained that the three of them had to make decisions on what topics they wanted to cover during the sessions and told the two tutors in advance so that the latter could come to the meetings prepared. This unexpected situation also led the three students to develop a practice of meeting regularly outside the weekly sessions to review class notes and discuss essay ideas. Sasha believed the extended time they spent outside the scheduled sessions helped strengthen a trusting, collaborative relationship and a sense of community among the three students.

This group was labeled as "student-led" also because the two tutors adopted a rather "classic" non-directive, peer tutoring approach by engaging students in self-driven learning (Hathaway, 20I5) and viewed themselves as facilitators, similar to their colleagues in Group I. For example, one of the tutors, Ailbe, talked about her preference of "process-focused" over "product-focused" strategies and emphasized the "discovery phase" during the group tutoring sessions. In addition, Ailbe wanted the writers to go beyond merely finishing the class assignments and become "independent learners" who develop generalizable writing and learning skills and "[a] better sense about yourself as a learner" by the end of the term. 
Furthermore, both tutors mentioned that they were very conscious about the power dynamics between themselves and the students and made efforts to "weaken the traditional structure between tutors and tutees" (Thad, the other tutor). The positive side of this non-directive, "hands-off" practice was that the students did assume leading roles in the group. However, students felt that the tutors were not "managing the time productively" because the two tutors often "ended up Google-ing with us" (Sasha). When being asked about the "Google-ing" scenario, which was also documented in the observation, both tutors, however, interpreted this activity of searching information about a new concept online along with the students as a way to engage in collaborative inquiry with the students as peer learners, as opposed to assuming a more directive, authoritative role by giving an answer. This practice did not meet the expectations of the students and consequently led the students to take more autonomy on their learning, which was, ironically, the original intent of the tutors.

\section{Group III: Tutor-directed Group}

Students in Group III devoted the most time on writing-related activities because the class they were taking was a mandatory composition class that aimed to introduce students to the interdisciplinary academic (English) writing. Therefore, all students in this group explicitly wanted to use this program to improve their English writing skills and get help from the two tutors, who were both English majors. For example, Rebecca, one of the students, reported that she wanted to improve "writing skills, like, how to better organize and make, like, better sentences when I am writing." Similarly, another student in the group, Wei, explained that he mostly needed help on writing his papers, especially flow and organization, which was one of the learning objectives from the class. As a result, many of the group activities focused on either specific writing assignments or aspects of English writing process in general, such as constructing complex claims, analyzing and synthesizing multiple sources, and editing and revising.

This group was categorized as "tutor-directed" because the two tutors led most of the sessions and suggested activities for the group. However, the students did not always respond to the tutors' suggestions in a positive way. In one week's meeting, the tutors invited the students to reflect on the writing process of a paper they submitted earlier in the week. Both Wei and Ang (the third student) strongly opposed this idea and Rebecca was reluctant, seeing little point of discussing an assignment they had already completed. The two tutors later explained during the interviews that they, drawing from their own writing experiences and tutoring training, thought this activity would help the students become more conscious about their writing process and would benefit their future writing projects. They finally dropped this idea after several failed prompts and suggested something else.

In addition, very few student-student interactions were observed. The group meetings often turned into concurrent one-to-one sessions between one tutor and one or two students. When the tutors attempted to engage the students in group discussion, it was not uncommon for the students to speak to the tutors about their opinions about the paper of another student's instead of talking directly to that person. Both tutors were aware of this pattern and deliberately encouraged interaction among students. The following excerpts were from a peer review of
Rebecca's paper on the inequality of the U.S. education, facilitated by Catherine, one of the tutors:

Ang: (to Catherine) Unequal rights, I think that's what she's trying to say...

Catherine: (to Ang) Why don't you ask...

Ang:What?

Catherine: (pointing to Rebecca) Ask her...ask Rebecca, we are talking to each other.

Ang turned his head to Rebecca, saying nothing, and turned away immediately. The lack of engagement in group activities led to limited social interaction and consequently a low sense of community among students in this group, which was also reported by participants during the interviews: neither Rebecca nor Wei expressed a strong motivation to develop the kind of close relationship observed in the other two groups. This lack of a sense of belonging confirmed Wenger's (1998) caution that a community of practice would not necessarily emerge simply by arranging a group of people together but needs to be carefully cultivated.

\section{SUMMARY OF FINDINGS}

The three groups in this study represented different types of communities: Group I displayed the most salient characteristics of a CoP where students developed shared goals of understanding course materials and improving English writing skills and participated in learning activities that were valued by the whole group. They also shared learning responsibilities that held the group together, indicated by their active interaction among themselves and with the tutors (Wenger et al., 2002). Students in Group II similarly showed high level of commitment to the group and developed activities around their shared learning goals, indicators of a CoP.The two tutors, however, were largely marginalized in the community and from the joint practices developed by the students. Students in Group III, while sharing the concern of improving their English writing skills, developed the least level of sense of community, suggested by the limited interaction and the almost absence of collaborative learning within the group (Wenger, 1998).

\section{DISCUSSION}

Study findings revealed that the three groups differed significantly in ways these international ELL student writers and peer writing tutors negotiated their roles and priorities, and interacted and collaborated within the groups. These findings were discussed around the three themes emerged across groups that appeared to have influenced international ELL student learning in this program.

\section{Mismatch between Student Goals and Tutor Goals}

The sustaining of the CoPs depends greatly on the domain of knowledge that creates a perceived common ground and shared goals for community members to participate in community practices (Wenger et al., 2002). In this study, students across three groups were mainly motivated by two goals: I) getting help with English writing for class assignments; and 2) understanding disciplinary content, both of which were immediate, short-term learning goals directly relevant to the courses they were taking. This emphasis on short-term goals was consistent with their perceived learning benefits from participating in this program, including receiving feedback on their writing assignments, getting help with 
class materials, and accessing to the expertise of peers and peer tutors. These perceived values were conductive to the sustaining of the CoPs and experiences of the community members (Wenger et al, 2002).

By contrast, the tutors were less concerned about the immediate product than the writing process and the potential longterm application of learning skills and writing strategies students were to learn from this program. For example, Evelyn explained that helping the writers apply what they learned in the group for the longer-term development was her motivation of taking this job and that she wanted her writers to "learn these skills for long-term usage, outside the class, outside the university." The reflection activity suggested by the two tutors in Group III, despite being rejected by the students, also showed their attempt to help students develop generalizable skills. This emphasis on forward-oriented goals was consistent with the philosophy of the writing center and the tutor training that focused on cultivating student writers' knowledge and skills beyond the immediately learning tasks.

However, this mismatch between the tutor and student goals became a source of conflicts and tensions. Direct resistance from students was observed in both Groups II and III, most evidently by the scenario aforementioned when students in Group III rejected tutors' suggestion of reflecting on an assignment that they had already submitted. Alternatively, students started practices that they believed would increase the value of staying in the group, such as spending extra time outside the weekly sessions as Group II did. In both cases, students expected to receive more direct guidance on the learning tasks from their tutors, who instead adopted the non-directive peer tutoring approach and focused less on the specific writing products than the process of writing. This mismatch suggested that these writing tutors might not expect, or were not prepared, to provide the kinds of writing support expected by ELL students and were not sufficiently responsive to the linguistic and learning needs of these students.

\section{Mismatch between Tutors' Expected and Enacted Roles}

Relatedly, there was a mismatch between students' expected roles of their tutors and the tutors' enacted roles. Students in all three groups reported that they expected their tutors to play a somewhat authoritative, expert role so that they could "learn" from the tutors' writing and content knowledge and be "guided" by the tutors. On the contrary, all six tutors wanted to play a non-directive, "facilitator" role based on the peer learning principle. When students found that the ways their tutors performed did not match their expectations, they either tried to push them into an expert role, which was partially accepted by tutors in Group I; or experienced frustration (Group II) and resistance (Group III) when the tutors refused. The first group seemed to work the best when the tutors were able to recognize the learning needs of the students, adjust their strategies, and negotiated practices with the students.

The main duties of tutors during group meetings included planning and proposing weekly topics, facilitating discussions and group activities, seeking input from students by asking questions, and maintaining the discussion flow and group dynamics. These activities reflected the idea of peer tutoring that engaged writers in conversation and self-directed, collaborative learning in an informal environment (Harris, 1995). Ailbe and Thad in Group II played roles closest to peer tutors and positioned themselves as peer learners who were not expert in content knowledge (international studies). However, this role perception became a source of disappointment and frustration among students in this group, who believed that their learning experiences and learning efficiency were sacrificed by the tutors' lack of content familiarity and the perceived disorganization of the peer learning activities. In the extreme case, Wei in Group III felt that the tutors' insistence on non-directive approach was almost too pretentious to the extent that they were being non-directive "just for the sake of being non-directive," even after it became clear that this approach was not working and resisted by the students. In other words, the tutors' unwillingness to adapt their approaches, ironically, was perceived by student writers as the de facto directive demands.

Compared with their colleagues' compliance to the standard, non-directive dogma, Yuan and Evelyn in Group I were more flexible in negotiating their roles and adjusting their practices in response to the needs of the students. This approach could be characterized as "proactive non-directive": that is, they were willing to strategically contribute their content expertise (Evelyn) or take initiatives when they saw the need to move the conversation to a different direction (Yuan). This practice of being proactive did not sacrifice the general non-directive principle or the goals of engaging students in active and collaborative learning, which was documented in the observation and confirmed during the interview with Patricia. In so doing, they were not only responding positively to the learning needs of the students, but also collaborating with students to develop shared practices and (re)negotiate their roles in working with ELL students in a peer learning community, which had the potentials to inform their practices for future sessions and the practices of their colleagues. In this sense, the two tutors were able to create "new possibilities for meaning" (Wenger, 1998, p. 109) for their tutoring practices.

\section{Group Dynamics}

The group dynamics that influenced the participation of the students operated both among students and between students and tutors. Students in Groups I and II shared relatively equal roles, established norms that regulated their practices in the group, and participated actively in group activities, all of which fostered a sense of community (Wenger, 1998). They also collaboratively shared learning responsibilities and responded positively to their peers' contributions. Both Groups I and II exemplified a collaborative knowledge construction that was based on collectively agreed-upon domain of knowledge and practices shared by the community members (Wenger et al., 2002). Such positive group dynamics enabled group members to develop ideas, seek and give help, and hold each other accountable (Blumenfeld et al., 1996). However, what distinguished Group I and Group II was the different dynamics between students and tutors. In Group I, the trusting and collaborative relationships among the students were extended to the two tutors, whose contributions were fully recognized by the students. In Group II, by contrast, it was almost of a sense of "crisis" among the students-a shared disappointment and lack of confidence of the tutors - that strengthened the sense of community among the three students, yet adversely influenced their perceptions of and relationships with the two tutors.

Group III showed the lowest level of group interaction and most explicit conflicts among the students and between students and the tutors. When asked her interpretation of Ang's passive 
aggressive behavior documented earlier, Rebecca simply attributed it to Ang's "critical" personality and admitted that that was why she had little interaction with him. There were occasional collaborations between Ang and Wei and between Wei and Rebecca yet the group as a whole did not develop any shared, collaborative learning practice. Unlike their counterparts in Group II who sought support inward from each other, students in Group III did recognize their tutors' expertise and frequently sought help and requested advice from them, individually. However, an equal, collaborative relationship between the students and the tutors as a group was not observed and a learning community has yet to emerge.

\section{CONCLUSION}

This study contributed to the existing SoTL by extending the inquiry beyond the traditional, formal classroom setting to probe into the learning experiences of international ELL students in an informal, small-group tutoring program. Analysis of student learning in three groups revealed challenges they experienced in these communities, most notably a mismatch between students' goals and understandings of the program and the goals and practices of peer writing tutors working with them.

The identified mismatch suggested the need to reconceptualize the university writing center philosophies and practices, especially the take-for-granted, non-directive peer tutoring approach. None of the students interviewed in this study viewed their tutors as equal peers or facilitators; instead, they all expected tutors to assume a somewhat expert role who were knowledgeable of disciplinary content and English writing. This expectation was not unwarranted given WI courses' dual purposes of content learning with learning about writing. For these ELL students, it was in particular difficult to separate the process of learning to write-both academic English writing in general and writing in specific disciplinary genres-and writing to learn, either international studies (Groups I and II) (Hirvela, 20I I) or the English language (Group III) (Williams, 20I2). Most tutors in this study had limited understandings of the unique learning needs of their international ELL students and showed insufficient flexibility, insisting on the non-directive, peer tutoring approach even when it did not appear to work.

However, as Evelyn and Yuan in Group I demonstrated, the group worked the best when writing tutors assumed an in-between role of collaborative peer and expert, proactively responded to the specific learning needs of the students, and collaboratively negotiated learning goals and constructed learning activities with the students. As a result, Evelyn observed that students in her group were "constantly doing well" and were "in a better place of writing" by the end of the term, which suggested the potentials of this approach. This is not to say that writing tutors should avoid non-directive approaches with international ELL students all together. Writing center administrators and writing tutors-especially those who work with culturally and linguistically diverse writers, including international ELL studentsshould go beyond the directive vs. non-directive dichotomy and pay greater attention to the merits and limits of each approach and be flexible in shifting their tutoring methods as needed when working with students with diverse linguistic backgrounds and learning needs.

In addition, ELL students appear to be benefited from being paired with tutors familiar with the course content who can broker both English writing strategies and disciplinary knowledge for international ELL writers who are new to the English academic community and make connections between writing to learn disciplinary content and learning to write in English (Manchón, 20 I I). Tutors playing a more proactive role can also serve as cultural informants who can share their cultural and educational experiences with ELL students and help them adapt to the college learning community (Cheatle, 20I7). Therefore, it is necessary to incorporate into writing tutor training targeted strategies about working with international ELL students, as well as other culturally and linguistically diverse students, so that they can better respond to the learning needs of an increasingly diverse student population. This addition is imperative given the increasingly internationalization of higher education in the world and the growing number of international students in colleges and universities in the U.S.

While this study did not assess student performance and improvement in these groups, all four students interviewed reported that they benefited from participating in this program, though mostly pertaining to the immediate values towards the courses they were taking. It has been documented in SoTL that collaborative peer learning opportunities support students' reflective and interactive learning and engagement with multiple perspectives (Tsang, 20I I) and have a positive impact on students' academic competence and sense of belonging to the college community by constructing social connections with other students (Glaser et al., 2006; Roscoe \& Chi, 2008). Future studies investigating the long-term impact of collaborative learning programs similar to the one reported in this article may shed additional light on better supporting the growing international and ELL students in the higher education institutions in the U.S. and beyond. Other areas for future research include a more nuanced analysis of the benefits and limitations of directive and non-directive approaches, impact of writing tutors' linguistic backgrounds (native speakers of English or the first language of the students) and institutional support needed to enhance tutor facilitating multilingual/cultural learning communities. One limitation of this study is the missing of the perspectives of the students who declined to be interviewed. Future studies that investigate the challenges of these students would provide important insights by examining their less-engaged participation. Collectively, this line of inquiry will help advance toward the ultimate goal of SoTL to improve student learning (Gilpin, 20I I) and continuously inform transformative teaching practices and SoTL initiatives (Gilpin \& Liston, 2009).

\section{ACKNOWLEDGEMENTS}

I thank Dr. Mike Knapp, Dr. Kara Jackson, and Dr. Heather Hebard for their expertise and comments on earlier drafts of this article. I am also grateful for the constructive feedback and helpful suggestions provided by the reviewers and journal editors. Finally, I thank Jenny Halpin and all my participants, without whom this study would not have been possible. 


\section{REFERENCES}

Aitchison, C. (2009). Writing groups for doctoral education. Studies in Higher Education, 34(8), 905-916.

Aitchison, C., \& Guerin, C. (Eds.). (20I4). Writing groups for doctoral education and beyond: Innovations in practice and theory. New York, NY: Routledge.

Blau, S., Hall, J., Davis, J., \& Gravitz, L. (200I).Tutoring ESL students: A different kind of session. Writing Lab Newsletter, 25(I0), I -4.

Blau, S., Hall, J., \& Sparks, S. (2002). Guilt-free tutoring: Rethinking how we tutor non-native-English-speaking students. The Writing Center Journal, 23(I), 23-44.

Blumenfeld, P. C., Marx, R. W., Soloway, E., \& Krajcik, J. (1996). Learning with peers: From small group cooperation to collaborative communities. Educational Researcher, 25(8), 37-40.

Bruffee, K.A. (1984). Peer tutoring and the conversation of mankind. In G. Olsen (Ed.), Writing centers:Theory and administration (PP. 3- I5). Urbana, IL: NCTE.

Bruffee, K. A. (1998). Collaborative learning: Higher education, interdependence, and the authority of knowledge. Baltimore: MD: The Johns Hopkins University Press.

Caplan, N. A., \& Stevens, S. G. (2017). "Step out of the cycle": Needs, challenges, and successes of international undergraduates at a U.S. University. English for Specific Purposes, 46, I5-28.

Cheatle, J. (2017). Challenging perceptions: Exploring the relationship between ELL students and writing centers. Praxis: $A$ Writing Center Journal, I 4(3), 2 I-3I.

Corbin, J., \& Strauss, A. L. (20 I 5). Basics of qualitative research:Techniques and procedures for developing grounded theory (4th ed.). Thousand Oaks, CA: SAGE.

Cox, M. (20II). WAC: Closing doors or opening doors for second language writers? Across the Disciplines, 8(4). Retrieved from https://wac.colostate.edu/atd/ell/cox.cfm

Cox, M., \& Zawacki, T. M. (20I4). Introduction. In T. M. Zawacki \& M. Cox (Eds.), WAC and second-language writers: Towards linguistically and culturally inclusive programs and practices (Pp. 15-40). Fort Collins, CO:The WAC Clearinghouse.

Fernsten, L. (2008). Writer identity and ESL learners. Journal of Adolescent \& Adult Literacy, 52(I), 44-52.

Gillespie, P., \& Lerner, N. (2008). The Longman guide to peer tutoring $\left(2^{\text {nd }}\right.$ ed.). London, UK: Pearson.

Gilpin, L. S. (20I I). Scholarship of teaching and learning trades. International Journal for the Scholarship of Teaching and Learning, 5(2), Article 4. https://doi.org/https://doi.org// 0.20429/ ijsotl.20I I.050204

Gilpin, L. S., \& Liston, D. (2009). Transformative education in the scholarship of teaching and learning: An analysis of SoTL literature. International Journal for the Scholarship of Teaching and Learning, 3(2), Article II. https://doi.org/https://doi. org/ / 0.20429/ijsotl.2009.0302 I I

Glaser, N., Hall, R., \& Halperin, S. (2006). Students supporting students:The effects of peer mentoring on transition, belonging and retention among first year university students. Journal of the Australian and New Zealand Student Services Association, 27(I), 4-19.

Griswold, G. (2003). Writing centers: The student retention connection. Academic Exchange Quarterly, 7(7), 277-282.

Harris, M. (1995). Talking in the middle:Why writers need writing tutors. College English, 57(I), 27-42.
Hathaway, J. (20I5). Developing that voice: Locating academic writing tuition in the mainstream of higher education. Teaching in Higher Education, 20(5), 506-5 I 7.

Hirvela, A. (20I I). Writing to learn in content areas: Research insights. In R. Manchón (Ed.), Learning-to-writer and writingto-learn in an additional language (pp. I59-180). Amsterdam, AN: Benjamins.

Institute of International Education (2020). Open Doors 2020: Report on International Education Exchange. Washington, DC: National Press Club.

Kim, J. (20I2). The birth of academic subalterns: How do foreign students embody the global hegemony of American universities? Journal of Studies in International Education, I6(5), 455476.

Lave, J., \& Wenger, E. (199I). Situated learning: Legitimate peripheral participation. Cambridge, UK: Cambridge University Press.

Lin, S. M. (20I5). A study of ELL students' writing difficulties: A call for culturally, linguistically, and psychologically responsive teaching. College Student Journal, 49(2), 237-250.

Lunsford, A. A. (|99|). Collaboration, control, and the idea of a writing center. The Writing Center Journal, I2(I), 3-I0.

Manchón, R. (20I I). Writing to learn the language: Issues in theory and research. In R. Manchón (Ed.), Learning-to-write and writing-to-learn in an additional language (pp. 6I-84). Amsterdam, AN: Benjamins.

Merriam, S. B., \& Tisdell, E. J. (20I6). Qualitative research: A guide to design and implementation (4th ed.). Hoboken, NJ: JosseyBass.

Moussu, L., \& David, N. (20I5). Writing centers: Finding a center for ESL writers. In N.W. Evans, N. J. Anderson, \& W. G. Eggington (Eds.), ESL readers and writers in higher education: Understanding challenges, providing support (pp. 49-63). New York, NY: Routledge.

Munje, P. N., Nanima, R. D., \& Clarence, S. (20I8). The role of questioning in writing tutorials: A critical approach to student-centered learning in peer tutorials in higher education. Mentoring \& Tutoring: Partnership in Learning, 26(3), 336-353.

Nan, F. (20/2). Bridging the gap: Essential issues to address in recurring writing center appointments with Chinese ELL students. The Writing Center Journal, 32(I), 50-63.

Powers, J., \& Nelson, J. (1995). L2 writers and the writing center: A national survey of writing center conferencing at graduate institutions. Journal of Second Language Writing, 4(2), I I 3- I 38.

Roscoe, R. D., \& Chi, M.T.H. (2007). Understanding tutor learning: Knowledge-building and knowledge-telling in peer tutors' explanations and questions. Review of Educational Research, 77(4), 534-574.

Shehadeh, A. (20I I). Effects and student perceptions of collaborative writing in L2. Journal of Second Language Writing, 20(4), 286-305

Thonus, T. (2014). Tutoring multilingual students: Shattering the myths. Journal of College Reading and Learning, 44(2), 200-2I3.

Tsang, A. (20II). In-class reflective group discussion as a strategy for the development of students as evolving professionals. International Journal for the Scholarship of Teaching and Learning, 5(I), Article 7. https://doi.org/https://doi.org/10.20429/ ijsotl.201 I.050107

Wenger, E. (1998). Communities of practice: Learning, meaning, and identity. Cambridge, UK: Cambridge University Press. 
Wenger, E., McDermott, R., \& Snyder, W. (2002). Cultivating communities of practice:A guide to managing knowledge. Cambridge, MA: Harvard Business School Press.

Wigglesworth, G., \& Storch, N. (20I2). What role for collaboration in writing and writing feedback. Journal of Second Language Writing, 2 I (4), 364-374.

Williams, J. (2012). The potential role(s) of writing in second language development. Journal of Second Language Writing, 2 I (4), $32|-33|$.

Williams, J., \& Severino, C. (2004). The writing center and second language writers. Journal of Second Language Writing, 13(3), 165-172.

Williams, J. D., \& Takaku, S. (20I I). Help seeking, self-efficacy, and writing performance among college students. Journal of Writing Research, 3(1), I- I8.

Yin, R. K. (2017). Case study research and applications: Design and methods (6th ed.). SAGE. 